\title{
Colpoplasty and Acute Pneumonitis
}

\author{
Ulrich Costabel \\ Department of Pneumology and Allergy, Ruhrlandklinik, Essen, Germany
}

How can BAL be helpful to elucidate pulmonary complications arising from changes in the vaginal wall? The answer is given in a case report by Kim et al. [1] in this issue of Respiration. The authors report the case of a 46year-old woman who was admitted to hospital with acute respiratory failure resulting from acute pneumonitis requiring immediate intubation and mechanical ventilation. The patient improved after empirical treatment with intravenous steroids and intensive supportive therapy so that she could be extubated after 10 days. To clarify the underlying cause of the acute pneumonitis, a BAL was performed on the 16th hospital day and disclosed large pleomorphic cytoplasmic inclusions in alveolar macrophages. Transbronchial lung biopsy showed similar alterations.

These findings documented pulmonary involvement associated with silicone injection into the vaginal wall for colpoplasty which had been performed 2 days before hospital admission. This illegal practice is done in Korea by unqualified people and obviously carries increased risks of pulmonary complications, since 3 other cases have been reported exclusively in the Korean literature (2 with pulmonary embolism, 1 with ARDS) $[2,3]$. The likely mechanism involves local tissue damage and entry of the injected substance into the blood stream [4].

What do we learn from this case report? First, silicone injections, mainly used for breast augmentation, are also applied at unusual body sites, and this fact should be considered when pulmonary complications are suspected. Second, acute pneumonitis resulting from silicone injection has to be added to the list of conditions for which characteristic morphologic changes of BAL cells can offer diagnostic clues. This is another good example that the BAL analysis should not be limited to the performance of differential cell counts but that knowledge of the morphologic appearance of BAL cells is also important.

\footnotetext{
References $\quad 1$ Kim CH, Chung DH, Yoo C-G, Lee C-T, Han SK, Shim Y-S, Kim YW: A case of acute pneumonitis induced by injection of silicone for colpoplasty. Respiration 2003;70:104-106.

2 Jung BH, Suh YI, Lee JM, Song SH, Kim HJ, Lee MG, Hyun IG, Jung KS, Shin HS: Two cases of silicone-induced pulmonary embolism. Tuberc Respir Dis 1993;40:610-615.

3 Kang MB, Kim ST, Lee JG, Seo CJ, Lee HE, Jeon JB, Kim SG, Kim C, Park JW, Jeong SW, Nam GH: A case of acute respiratory distress syndrome with pulmonary embolism induced by injection of silicone at vaginal wall. Tuberc Respir Dis 1999;46:414-419.

4 Chastre J, Brun P, Soler P, Basset F, Trouillet JL, Fagon JY, Gibert C, Hance AJ: Acute and latent pneumonitis after subcutaneous injections of silicone in transsexual men. Am Rev Respir Dis 1987;135:236-240.
}

\begin{tabular}{ll}
\hline KARGER & ○ 2003 S. Karger AG, Basel \\
Fax +41 61 306 12 34 & 0025-7931/03/0701-0031\$19.50/0 \\
$\begin{array}{l}\text { E-Mail karger@karger.ch } \\
\text { www.karger.com }\end{array}$ & $\begin{array}{l}\text { Accessible online at: } \\
\text { www.karger.com/res }\end{array}$
\end{tabular}

Ulrich Costabel, MD
Chief, Department of Pneumology and Allergy, Ruhrlandklinik
Tueschener Weg 40
D-45239 Essen (Germany)
Tel. +49 201433 4020, Fax +49 201433 4029, E-Mail erj.costabel@t-online.de 